\title{
Indirect Tax and Employment Generation in Nigeria
}

\author{
George-Anokwuru Chidinma Chioma. B. \\ Olisa Felix Ubaka ${ }^{2}$ \\ Obayori, Joseph Bidemi ${ }^{3 \rtimes}$
}

\author{
Department of Economics, Faculty of Social Sciences, University of Port Harcourt, Nigeria. \\ Email:chiomanwoga@yahoo.com Tel:+2348033427231 \\ 2 School of Graduate Studies University of Port Harcourt, Nigeria. \\ Email:ubaolisa1s@gmail.com Tel:+2348032628118 \\ Department of Economics, Faculty of Social Sciences, Nnamdi Azikiwe University, Awka, Nigeria. \\ Email:profobj2000@gmail.com Tel: +2348037655520
}

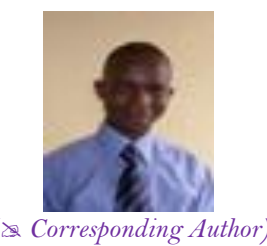

(A) Check for updates

\begin{abstract}
This paper empirically investigated indirect tax and employment generation in Nigeria from 1999 - 2019. The specific intentions of the study were to; examine the correlation between value added tax and employment generation in Nigeria and determine the impact of custom and excise duties on employment generation in Nigeria. Secondary data on employment rate, custom and excise duties as well as value added tax were collected from Central Bank of Nigeria statistical bulletin and the method of Dynamic Ordinary Least Square regression analysis was applied. Given the empirical results, the paper concluded that indirect tax measures by value added tax (VAT) has a direct link with employment rate. Also, custom and excise duties have a significant impact on employment generation in Nigeria. Based on the empirical findings, the study recommended amongst others that government should put in place adequate fiscal measure to ensure that revenue generated from indirect taxes is effectively utilize to develop and grow the economy through employment generation.
\end{abstract}

Keywords: Benefit theory, Custom duty, Employment, Generation, Indirect tax, DOLS, VAT.

JEL Classification: E24:62.

\section{Introduction}

One of the basic targets of fiscal policy is to increase the rate of employment vis-à-vis the utilization of either the direct or indirect tax revenue. Meanwhile, the most and efficient of these two types of tax revenue is the indirect tax; this is because the tax payers find it very difficult to evade most forms of indirect tax such as value added tax (Obayori \& Omekwe, 2019). Thus, the difficulties in its evasion bring about increase in the revenue base of government and in the long run it will results to creation of employment for the citizenry. By means of definition, an indirect tax is a type of tax in which the payers, (the final consumers) bears the final burden. Also, it is a type of tax collected by an intermediate from the individual who bears the eventual economic liability of the tax and the intermediate later files a tax return and forwards the tax proceeds to government. Thus, an indirect tax may be used to raise the price of products for consumers. At such, an indirect tax is a regressive tax since both high and the low income earners pay the same tax amount for consumption of certain quantity of specified commodities. Examples of such tax include; sales tax, value added tax (VAT), custom and excise duties; import and export duties. On the other hand, Obayori and Robinson (2019) defined employment as a state in which individuals who are eager to work at a predominant wage rate by law are adequately engaged. In other words, employment is created when openings for work could be given by the legislature through government fund in the arrangement of social and financial framework in the economy Maeba (2019).

Meanwhile, before the 1970s, indirect tax revenue from non-oil sector was the principal source of financing government budget in Nigeria. By then graduate and youth unemployment was not a serious macroeconomic problem as it is today. But as government shift attention to direct tax revenue from the oil sector since the 1970s till date, employment generation has been the bane of Nigeria government. This is because, people have the mentality that crude oil is the free gift of nature and it will never go in extinction. This belief may be what warranted lack of prudence use of the revenue from the oil sector to counteract macroeconomic problem such as unemployment and stunted growth. For instance, the oil sector which accounted for over 90 per cent of export earnings and more than 80 per cent of government revenue since 1970 s still maintain the same trend till date. But it is alarming that employment generation does not correspond with the increase in the direct tax revenue from the oil sector as youth unemployment has risen to about 60\% today (Obayori \& Robinson, 2019).

Given the volatility in the crude oil price at the international market, constantly relying on revenue from it to promote fiscal sustainability and growth will be detrimental to the developmental process of the Nigerian economy. Hence the need to have a mix of revenue sources to boost the nation's revenue base through efficient management of suitable fiscal policies (Jones \& Ekwueme, 2016). Similarly, since direct tax revenue from petroleum products is not healthy for sustainable economic growth as a result of fluctuation in the crude oil prices in the international 
market, hence the need for a paradigm shift to tax revenue and particularly to indirect tax such as value added tax and customs and excise duties, which are easier to collect and less prone to evasion. The revenue collected from these sources will help the government achieve full employment in the short run and economic development in the long run through judicious use of the tax revenues (Nmesirionye, Jones, \& Onuche, 2019). Given this assumption, Nigeria government uses various indirect taxes revenue such as the ones from value added, custom and excise duties amongst others to counteract the problem of chronic unemployment rate that has risen from less than $9 \%$ in the 1970 s to about $25 \%$ in 2018 (National Bureau of Statistics (NBS), 2019).

Given the background above, the paper empirically examined the impact of indirect tax on employment generation in Nigeria by answering the following questions; what is $t h$ e relationship between VAT and employment generation? How has excise and custom duties impacted on increase in employment in Nigeria? Thus, the objectives of the study were to; examine the relationship between value added tax and employment generation in Nigeria and determine the impact of custom and excise duties on employment generation in Nigeria since the return to full democracy in 1999. Moreover, this paper is one of the very few studies that examined indirect tax and employment generation. This is because; most of the existing studies examined the effect of tax on economic growth over different data periods. Since it was realized that there is hardly any work on the effect of indirect tax on employment generation in Nigeria; this study filled this research gap.

\section{Review of Related Literature}

\subsection{Theoretical Review: Benefit Theory of Tax}

According to the renowned economists; Knut and Lindahl (1967) taxes should be paid for consumed public commodities by individuals based on benefits received. In other words, tax is directly proportional to state derived activities (Bhartia, 2009). This simply connote that the more profits an individual enjoys from government activities, the more such individual should pay to the government. A true picture of this theory is the taxes collected in every local authorities, such as market place, bus stop amongst others, which in the long run will be used to develop various social services which results to social benefit to the citizenry. Thus, the public service enjoys is a function of tax revenue derived from the benefit people enjoy.

The theory has been subjected to various criticisms on the ground that; (i) Benefit is absolutely an abstract issue and there is no logical method to gauge the extent of advantage and its money value. (ii) If benefits accumulated to an individual are the premise of tax collection, the poor must pay higher on the grounds that in a welfare economy, the poor get a larger number of advantages than the rich. This is plainly out of line and as such an inadmissible suggestion (iii) The equitable distribution of wealth, the main objective of most of the modern governments will be defeated if this principle is followed.

\subsection{Empirical Review and Justification of the Study}

Empirical works of scholars who examined the nexuses between various indirect taxes and economic performance such as economic growth and employment/unemployment were identified. Such scholarship include; Nmesirionye et al. (2019) who looked at indirect taxes and the performance of the Nigerian economy as of 1994 to 2017 with the use of Ordinary Least Square. The findings revealed that VAT has direct impact on GDP of Nigeria while custom and excise duties has significant positive impact on GDP in Nigeria. Also, Obayori and Omekwe (2019) used ARDL model to examine indirect tax and economic growth in Nigeria. They concluded that VAT as an indirect tax system in Nigeria has direct influence on economic growth in Nigeria since its inception in 1994. Inimino, Otubu, and Akpan (2018) used ECM to examine VAT as a form of indirect tax and economic growth in Nigeria from 1994 to 2015. They established that VAT, exchange rate and interest rate all impacted on economic growth in Nigeria. But private domestic investment does not impact on economic growth. Akhor and Ekundayo (2016) used ECM to consider indirect tax revenue and Nigeria GDP for the period 1993-2013. They averred that VAT had a direct impact on GDP while excise duty had an inverse impact on GDP. Okunbor and Izedonmi (2014) used linear regression to examine the contribution of VAT to the development of the Nigerian economy from 1994 to 2010. The result of their findings revealed that VAT revenue and total revenue accounted for almost $92 \%$ deviations in GDP in Nigeria. Ihendinihu, Jones, and Ibanichuka (2014) investigated the long-run equilibrium nexus between tax revenue and economic growth in Nigeria from 1986 to 2012 with the use of ARDL technique and found that VAT has no statistical significant impact on economic growth in Nigeria. Johnson (2013) examined the impact of tax policy on inflation and unemployment in Nigeria from 1970 to 2008. The OLS estimations showed that taxes have a negative effect on both inflation and unemployment rates but with insignificant coefficient. Ilaboya and Mgbame (2012) investigated indirect tax-economic growth dynamics from 1980-2011 with the use of error correction mechanism. They found an indirect and insignificant connection between indirect tax and economic growth in Nigeria.

Meanwhile, existing empirical studies revealed that several research explorations have examined the effects of indirect tax on economic growth and other macroeconomic variables over different data periods. Also, the empirical review exposed that most of the studies of particular interest applied different estimation techniques in their analysis, such as Ordinary Least Squares, cointegration and error correction technique and ARDL. But these empirical studies reached different conclusions about the influence of indirect tax on economic fundamentals, which cannot be generalised for policy decisions. But from the scholarship, it was realized that hardly is there any work on the effect of indirect tax on employment generation in Nigeria; this study filled this research gap. This was done by using the technique of dynamic ordinary least square (DOLS) to examine indirect tax and employment generation in Nigeria. It also, extends the period of study to 2019 in order to capture realities of recent policy actions on employment creation in Nigeria.

\section{Methodology}

The data ranges from the period of 1999 to 2019. This data was mainly sourced from the publications of the Central Bank of Nigeria (CBN) statistical bulletin volume 30, 2019. This study adopted the econometrics method of dynamic ordinary least square (DOLS) to explore the impact of the explanatory variables (value added tax and 
custom/excise duties) on the dependent variable (employment rate). The essence of using the DOLS proposed by Stock and Watson (1993) is because it has the ability to eliminate endogeneity problem and it is robust to autocorrelation problem. Meanwhile, preliminary test via descriptive statistics was carried out to ascertain the characteristic nature of the time series under consideration. Also, stationarity test via ADF unit root test was carried out to establish stability of the time series. Also, co-integration test proposed by Johansen (1998) was conducted to ascertain the long-run equilibrium relationship among the variables

\subsection{Model Specification}

The empirical model for the study was cast in line with the model proposed by Nmesirionye et al. (2019) who used OLS to examine indirect taxes and performance of the Nigerian economy from 1994 to 2017. Their OLS model was in the form of GDP $=\mathrm{f}(\mathrm{VAT}, \mathrm{ECD}) \quad$ (1). Where GDP is economic performance, VAT is value added tax and ECD is excise duties. But the current model replaced GDP with employment generation (EPG) in the model. It also extend the time frame to 2019. Thus, DOLS model specified in log-linear econometric form is stated thus;

$$
\mathrm{EPG}=\lambda_{0}+\lambda_{1} \mathrm{LnVATt}+\lambda_{2} \mathrm{LnCUDt}+\sum_{i=1}^{n} \Delta \lambda_{1} \operatorname{LnVATt}-1+\sum_{i=1}^{n} \Delta \lambda_{2} \operatorname{LnCUDt}+\mu \mathrm{t}(2)
$$

Where; EPG is Employment Rate (proxy for employment generation), VAT is Value Added Tax, CUD is Custom and Excise Duties, $\mu$ is Error Term, $\lambda_{1}$ and $\lambda_{2}$ are Slope Parameters, $\lambda_{0}$ is Intercept Parameter and $\sum$ is summation.

\subsection{Description of the Variables}

Employment Generation: This is an economic situation in which people who are ready to work are productively employed to increase the production output of the economy. Employment generation was calculated as a percentage inverse rate of unemployment. The ideology was based on the formula proposed by Swane and Vistrand (2006).

Value Added Tax: This is a consumable levy imposed on goods whenever value is added at each stage of the supply chain. It is imputable on the supply of payable goods and services except otherwise specified. VAT can either be input VAT or output VAT. Therefore, it is anticipated that revenue from VAT will have a positive correlation with employment rate.

Custom and Exercise Duties: These are charges placed on goods imported to the country. This is anticipated that tax revenue from custom and exercise duties have a positive link with employment generation.

\section{Results and Discussion}

\subsection{Descriptive Statistic Result}

This section analyses the descriptive statistic in order to ascertain the nature and characteristic of the variable under study.

Table-1. Descriptive statistic result.

\begin{tabular}{c|c|c|c}
\hline \multicolumn{5}{c}{ Table-1. Descriptive statistic result. } \\
\hline Measurement & EPG & VAT & CUD \\
\hline Mean & 8.634762 & 410851.8 & 295553.3 \\
\hline Median & 8.700000 & 468400.0 & 297500.0 \\
\hline Std. Dev. & 1.576866 & 276697.7 & 129852.0 \\
\hline Skewness & 0.471666 & -0.169604 & -0.472708 \\
\hline Kurtosis & 2.024800 & 1.259734 & 2.166395 \\
\hline Jarque-Bera & 1.610780 & 2.750639 & 1.390120 \\
\hline Probability & 0.446914 & 0.252759 & 0.499044 \\
\hline Observations & 21 & 21 & 21 \\
\hline
\end{tabular}

The descriptive statistics reported in Table 1 indicated that employment rate (EPG) has an approximate average of 8.6percent with the corresponding standard deviation of 1.6percent. Similarly, Value added tax (VAT), has an approximate average of \$10852billion with the corresponding standard deviation of \$276698billion. Custom and excise duties (CUD), has an approximate average of $\$ 295553$ billion with the corresponding standard deviation of 129852billion. Thus, it can be infer from the analysis that the standard deviation of all the variables were not higher than respective averages. Therefore, they converged around their respective mean. Meanwhile, the skewness test showed a mixture of both negative and positive slopes. This negate the principle of consistency of result. Also, the probability of Jarque-Bera statistics showed that the null hypotheses of the variables were accepted. Thus, the variables were normally distributed.

\subsection{Unit Root Test}

The unit root test via Augmented Dickey Fuller (ADF) test was used to investigate the order of integration of the variables.

\begin{tabular}{|c|c|c|c|c|c|c|}
\hline Variables & $\begin{array}{c}\text { ADF Test } \\
\text { Statistic } @ \\
\text { Level }\end{array}$ & $\begin{array}{c}\text { ADF Test } \\
\text { Critical Value } \\
\text { a } 5 \% \text { (level) }\end{array}$ & $\begin{array}{c}\text { Order of } \\
\text { Integration }\end{array}$ & $\begin{array}{c}\text { ADF Test } \\
\text { Statistic @ } 1^{\text {st }} \\
\text { Difference }\end{array}$ & $\begin{array}{c}\text { ADF Test } \\
\text { Critical Value } \\
\text { a } 5 \%\left(1^{\text {st }} \text { Diff. }\right)\end{array}$ & $\begin{array}{c}\text { Order of } \\
\text { Integration }\end{array}$ \\
\hline $\mathrm{EPG}$ & 0.6698 & -3.0403 & Not Stationary & -8.8897 & -3.0403 & $1(1)$ \\
\hline VAT & 0.9940 & -3.0206 & Not Stationary & -5.7670 & -3.0299 & $\mathrm{I}(1)$ \\
\hline CUD & -1.4077 & -3.0206 & Not Stationary & -6.4119 & -3.0299 & $\mathrm{I}(\mathrm{I})$ \\
\hline
\end{tabular}


The unit root test of stationarity for the series via the ADF test shown on Table 2 disclosed that all the variables were not stationary at level, since their ADF test statistic values were far less than their critical values at $5 \%$. In view of this, the variables were differenced once and they became stationary at first difference prior to further estimations to avoid spurious regressions results when these variables were used in model estimations.

\subsection{Johansen Test for Co-Integration}

This part analyzed and discussed the co-integration result in order to validate economic assumption of long run association amongst variables.

Table-3. Johansen test for co-integration.

\begin{tabular}{|c|c|c|c|c|}
\hline Eigen value $K=1, r=2$ & Trace Statistics & $5 \%$ critical value & Prob. *** & Hypothesis of CE(s) \\
\hline 0.864005 & 56.71227 & 29.79707 & 0.0000 & None $*$ \\
\hline 0.607829 & 18.80465 & 15.49471 & 0.0153 & At most $1 *$ \\
\hline 0.052246 & 1.019546 & 3.841466 & 0.3126 & At most 2 \\
\hline Eigen value $K=1, r=2$ & Max-Eigen Statistic & $5 \%$ critical value & Prob. $* *$ & Hypothesis of CE(s) \\
\hline 0.864005 & 37.90762 & 21.13162 & 0.0001 & None* \\
\hline 0.607829 & 17.78510 & 14.26460 & 0.0133 & At most $1^{*}$ \\
\hline 0.052246 & 1.019546 & 3.841466 & 0.3126 & At most 2 \\
\hline
\end{tabular}

The results of the Johansen test of co-integration via both the Trace and Max-Eigen statistics, showed the existence of two co-integrating equations in the model at $5 \%$ level. Thus, the null hypothesis (Ho) of no cointegration among the variables was rejected. Based on this result, the paper concludes that there is a long run equilibrium relationship amongst the variables in the model.

\subsection{Discussion of Dynamic Ordinary Least Square Multiple Regression Result}

This section analyzed and discuss the regression result in line with the objectives of the study in order to validate economic assumptions.

Table-4. Dynamic ordinary least square regression result for the model.

\begin{tabular}{c|c|c|c|c}
\hline & \multicolumn{3}{|c}{ Dependent Variable: Employment Rate (EPG) } \\
\hline Variables & Coefficients & S-Error & t-statistics & Probability \\
\hline C & 81.18568 & 19.02463 & 4.267398 & 0.0021 \\
\hline Ln(VAT) & 1.482344 & 1.084835 & 1.366423 & 0.2050 \\
\hline Ln(CUD) & -7.244370 & 2.558989 & -2.830951 & 0.0107 \\
\hline Adjusted R ${ }^{2}$ & 0.8905 & f-statistics & 31.23672 & \\
\hline Durbin Watson & 1.6887 & Prob(F-stat) & $(0.0001)$ & \\
\hline
\end{tabular}

The results of the estimated model as presented in Table 4 showed that the adjusted R-squared is 0.8905 . Thus, the variation in employment rate (EPG) brought about VAT and custom and excise duties are $89 \%$. This shows that the model is a good fit. The Durbin Watson (DW) which measures the level of serial autocorrelation in an estimated model which was obtained via correlogram-Q-statistics test is 1.6887 . This value is very close to the DW bench mark of 2.0. Thus, it was infer that the model is free from problem of serial autocorrelation. Given the occurrence of no serial correlation, the estimated model is valid for policy making. In like manner, the f-statistics which measures the overall significant of the explanatory variables in the model showed that the two explanatory variables are significant in explaining employment generation in Nigeria. This is because, the probability of $\mathrm{f}-$ statistic of $0.0001<$ p-value of 0.05 .

Meanwhile, the results in Table 4 showed that, the value of Value Added Tax revenue (VAT) has a positive relationship but insignificant impact on employment rate (EPG). Thus, a percentage increase in VAT will causes an increase in employment by $1.48 \%$. The result conforms to the finding of Obayori and Omekwe (2019) as well as Onwuchekwa and Aruwa (2014) who examined the link between value added tax as a form of indirect tax and economic growth, and discovered that value added tax (VAT) has a direct relationship with economic growth in Nigeria. On the contrary, the value of custom and excise duties (CUD) has a negative relationship with employment rate but impacted significantly on employment rate. Thus, a percentage increase in custom and excise duties will decrease employment generation by $7.24 \%$. The finding supports the empirical work of Charles (2012) when he averred that the output growth is negatively influenced by indirect tax rate such as custom and excise duties. But negates the empirical finding of Obayori and Omekwe (2019).

\subsection{Post Estimation Test}

From the results of post estimation tests as depicted by both the normality and Wald tests. The estimated model is reliable for policy formulation. 


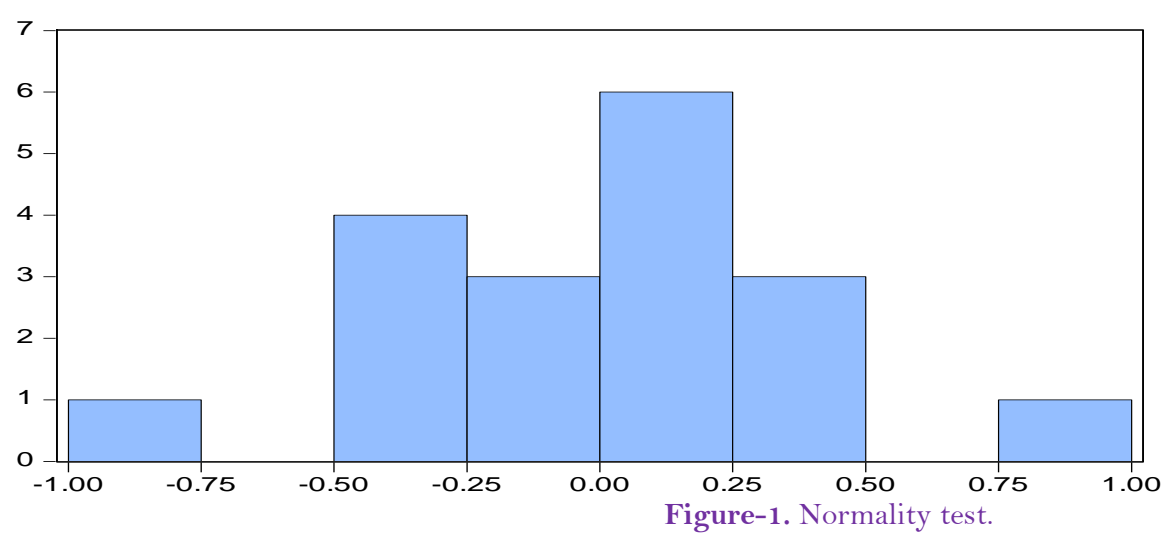

\begin{tabular}{lr} 
Series: Residuals \\
Sample 2001 2018 \\
Observations & 18 \\
Mean & $-8.37 e-15$ \\
Median & 0.041789 \\
Maximum & 0.756250 \\
Minimum & -0.842237 \\
Std. Dev. & 0.356017 \\
Skewness & -0.203826 \\
Kurtosis & 3.562123 \\
Jarque-Bera & 0.361622 \\
Probability & 0.834593 \\
\hline
\end{tabular}

The normality test as presented in Figure 1, showed that the error terms are normally distributed. This is because the probability values of the Jerque-Bera statistic (J-B stat) of 0.8345 is greater than 0.05 critical value. Thus, it was concluded that the sample data are normally distributed. The result meets the statistical criteria and authenticates the reliability of the estimated model for policy making.

The Wald test help to measure the significant of the explanatory variables in explaining the dependent variable in an estimated model. This was done by comparing the probability of f-statistic and P-value at $5 \%$. Thus, if the probability of f-statistic is less that $\mathrm{P}$-value at $5 \%$, we conclude that the explanatory variables are significant in explaining the dependent variable.

Table-5. Wald test.

Wald Test:
\begin{tabular}{c|c|c|c}
\hline \multicolumn{3}{l}{ Equation: Untitled } & \\
\hline Test Statistic & Value & Df & Probability \\
\hline F-statistic & 31.23672 & $(2,9)$ & 0.0001 \\
\hline Chi-square & 62.47344 & 2 & 0.0000 \\
\hline Normalized Restriction $(=0)$ & Value & Std. Err. \\
\hline \multicolumn{2}{c|}{$\mathrm{C}(1)$} & 1.482344 & 1.084835 \\
\hline $\mathrm{C}(2)$ & -7.244370 & 2.558989 \\
\hline
\end{tabular}

The estimated result in Table 5 showed that the f-statistics value of 31.2367 has the corresponding probability value of 0.0001 which is far less than 0.05 p-value at $5 \%$. Thus, it was concluded that the two explanatory variables (VAT and CUD) are significant in explaining employment generation in Nigeria during the studied period.

\section{Conclusion}

This paper empirically investigated indirect tax and employment generation in Nigeria from $1999-2019$. This was done against the background that since the return to full democracy in 1999, direct tax from petroleum products have not generated enough employment to propel the Nigerian economy to the desired level of growth and development due to the volatility of crude oil prices in the international market and mismanagement of the said revenue. Thus, a study of indirect tax was aim at increasing the revenue base of government and makes funds available for developmental purposes through increase in employment level and improved human development index. Based on the empirical results, it was concluded that indirect taxes measures by value added $\operatorname{tax}(\mathrm{VAT})$ as well as custom and excise duties has direct correlation and significant impact with employment generation and hence economic development in Nigeria. Following the empirical findings, the study recommends that government should put in place adequate fis cal measure to ensure that revenue generated from indirect taxes is effectively utilized to develop and grow the economy through employment generation. Also, given the indirect link between custom and excise duties with employment rate, it was recommended that all identified administrative loopholes should be plugged and well managed for custom and excise tax revenue to have direct relationship with employment rate in Nigeria.

\section{References}

Akhor, S. O., \& Ekundayo, O. U. (2016). The impact of indirect tax revenue on economic growth: The Nigeria experience. Igbinedion University Journal of Accounting, 2(08), 62-87.

Bhartia, H. L. (2009). Public finance (13th ed.). New Delhi: Vikas Publishing House PVT Ltd.

Charles, A. N. B. (2012). Investigating the performance of monetary policy on manufacturing sector in Nigeria. Arabian Journal of Business and Management Review, 2(1), 12-25. Available at: https://doi.org/10.12816/0002239.

Ihendinihu, J. U., Jones, E., \& Ibanichuka, E. A. (2014). Assessment of the long-run equilibrium relationship between tax revenue and economic growth in Nigeria: 1986 - 2012. The Standard International Journals, 2(2), $39-47$.

Ilaboya, O., \& Mgbame, C. (2012). Indirect tax and economic growth. Research Journal of Finance and Accounting, 3(11), 70-82.

Inimino, E. E., Otubu, O. P., \& Akpan, J. E. (2018). Value added tax and economic growth in Nigeria. International Journal of Research and Innovation in Social Science, 2(10), $211-219$

Johansen, S. (1998). Statistical analysis and co-integrating vectors. Journal of Economic Dynamics and Control, 12(2-3), $231-254$.

Johnson, A. A. (2013). Tax policy, inflation and unemployment in Nigeria. European Journal of Business Management, 5(15), 114-129. Available at: https://doi.org/10.1016/0165-1889(88)90041-3.

Jones, E., \& Ekwueme, C. D. (2016). Assessment of the impact of tax reforms on economic growth in Nigeria. Journal of Accounting and Financial Management, 2(2), 15-28.

Knut, W., \& Lindahl, E. (1967). The theory of public goods. The Scandinavian Journal of Economics, 105(4), 527-553. Available at: https://doi.org/10.1111/j.0347-0520.2003.00002.x.

Maeba, S. L. (2019). Effect of public expenditure on employment in Nigeria, 1980-2017. A Ph.D Thesis Submitted to Postgraduate School, Rivers State University, Port Harcourt Nigeria.

National Bureau of Statistics (NBS). (2019). General economic indicator. Abuja, Nigeria: Annual Abstract of Statistics.

Nmesirionye, J. A., Jones, E., \& Onuche, E. V. S. (2019). Impact of indirect taxes on economic performance of Nigeria (1994-2017). European Journal of Accounting, Finance and Investment, 5(4), 32-39. 
Obayori, J. B., \& Omekwe, S. P. O. (2019). Indirect tax and economic growth in Nigeria: The case of VAT. International Journal of Science and Management Studies, 2(6), 61-66.

Obayori, J. B., \& Robinson, M. O. (2019). Government spending in selected sectors and job creation in Nigeria. African Journal of Applied and Theoretical Economics, 5(1), 106-123.

Okunbor, J. A., \& Izedonmi, F. I. O. (2014). The roles of value added tax in the economic growth of Nigeria. British Journal of Economic Management and Trade, 4(12), 1999-2007. Available at: https://doi.org/10.9734/bjemt/2014/11013.

Onwuchekwa, J. C., \& Aruwa, S. A. (2014). Value added tax and economic growth in Nigeria. European Journal of Accounting Auditing and Finance Research, 2(8), 62-69.

Stock, J. H., \& Watson, M. W. (1993). A simple estimator of cointegrating vectors in higher order integrated systems. Econometrica, 61(4), 783-820. Available at: https://doi.org/10.2307/2951763.

Swane, A., \& Vistrand, H. (2006). Jobless growth in Sweden? A descriptive study. Being a Master's Thesis in International Economics and Business at Stockholm School of Economics.

Citation | George-Anokwuru Chidinma Chioma .B.; Olisa Felix

Ubaka; Obayori, Joseph Bidemi (2020). Indirect Tax and

Employment Generation in Nigeria. Asian Business Research

Journal, 5: 7-12.

History:

Received: 19 May 2020

Revised: 22 June 2020

Accepted: 24 July 2020

Published: 10 August 2020

Licensed: This work is licensed under a Creative Commons

Attribution 3.0 License (cc) EV

Publisher: Eastern Centre of Science and Education
Acknowledgement: All authors contributed equally to the conception and design of the study.

Funding: This study received no specific financial support.

Competing Interests: The authors declare that they have no competing interests.

Transparency: The authors confirm that the manuscript is an honest, accurate, and transparent account of the study was reported; that no vital features of the study have been omitted; and that any discrepancies from the study as planned have been explained.

Ethical: This study follows all ethical practices during writing.

Eastern Centre of Science and Education is not responsible or answerable for any loss, damage or liability, etc. caused in relation to/arising out of the use of the content. Any queries should be directed to the corresponding author of the article. 